\title{
Medical student's perception about virtual classroom during lockdown - a cross-sectional study
}

\author{
Udgiri, R.S. ${ }^{1}$, Biradar, S. $^{2}$
}

\begin{abstract}
Background: In the present scenario due to lockdown during the COVID-19 pandemic, online learning has become more prevalent all over the world. The sudden shift of the educational system from the traditional method of teaching to distance learning is one of the educational trials at present. Therefore it is required to know the student's perspectives about virtual classrooms.
\end{abstract}

Objectives: To analyze the perception of virtual classrooms among undergraduates and based on responses, necessary modifications are suggested to the university.

Methodology: It was a cross-sectional study. Institutional ethical clearance was taken before the start of the study. After taking consent from the students, the semi-structured questionnaires were sent to them online.

Results: In the present study, the perception of students with regards to the virtual classroom was good because it has many advantages like flexibility, accessibility from anywhere in the country.

Conclusion: The present study concludes that the use of virtual classrooms has many advantages and disadvantages. But at the same time, students preferred the traditional method as the best method of teaching.

Keywords: Medical students, Virtual classroom, Perception, Lockdown.

\section{Introduction}

A Virtual classroom is a form of online learning environment. Online learning has become more popular in the present scenario due to the COVID-19 pandemic, when the government of India declared lockdown all over India. The government's decisions have targeted the mutual goal of hindering the spread of COVID19 by maintaining social distance and avoiding face-to- face interaction like teaching.

${ }^{1}$ Department of Community Medicine, BLDE (DU)

Shri. B.M. Patil Medical College, Vijayapura,

Karanataka, India.

${ }^{2}$ Department of Ophthalmology, BLDE (DU) Shri.

B.M. Patil Medical College, Vijayapura, Karanataka, India

Corresponding author: Dr. Udgiri Rekha

drekhaudgiri@gmail.com
As a result, classes shifted from the classical classroom environment to online or virtual using the relevant technologies. The virtual classroom environment helps students to learn from anywhere maintaining social distance during this pandemic. The recently introduced competency-based curriculum has also advocated e-learning as an indispensable tool for self-directed learning (Saiyad, 2020). Online learning can bridge the gap and strengthen quantity and quality of medical education as it is flexible and adaptable. The sudden shift of the educational system from the traditional method of teaching to distance learning is one of the educational trials at present. Therefore it is required to know the student's perspectives about the virtual classroom. Based on the findings of the study, suggestions should be made to improve online learning.

DOI: http://doi.org/10.4038/seajme.v15i2.355 


\section{Objectives}

To analyze the perception of virtual classrooms among undergraduates and based on responses, necessary modifications are suggested to the university.

\section{Methodology}

The data was collected using an online questionnaire and confidentiality of those who gave responses and were included in the study was maintained. Students were asked to respond to questions about their adoption and use of virtual classrooms using a Likert scale. Each item is given a numerical score ranging from 1-5 (very poor $=1$, poor $=2$, fair $=3$, good= 4 , very good $=5$ ). Some of the questions were asked in the form of yes and no responses. For the open-ended question, respondents described their perception of virtual classroom experiences. Statistical analysis was done using SPSS version 20.

\section{Results}

A total of 130 students participated in the study. The majority of them were females and their mean age was $20.9 \pm 1.9$. $35 \%$ of them belong to III rd phase part-I followed by the III rd phase
Part-II. Among them $31 \%$ of the participants said they liked all the subject lectures of their subjects of study in the virtual classroom.

In the present study for structured questionnaires, we have observed statistically significant association between the participants of different professional years for all questions related to virtual classroom except, for the convenience of timing, on-significant association (Table 1). Some of questions were asked in the form of yes or no response. Positive response was observed among the different years of participants.

Similarly for the above responses, a statistically significant association was observed between male and female participants except for the few questions we observed non-significant association like- approaching the faculty easily and asking their doubt, faced any problem in managing attendance during online classes, and technical issues in connection to a virtual classroom.

For the open-ended questionnaires (repetition were avoided in the list), for the questions related to the advantages and disadvantages of virtual classroom. Following are the list mentioned by student responses.

Table 1: Association between structured liker scale responses with different professional years of the students

\begin{tabular}{|c|c|c|c|c|c|c|c|c|c|c|c|c|}
\hline \multirow[t]{2}{*}{ Parameters } & & \multicolumn{3}{|c|}{ MBBS I year } & \multicolumn{2}{|c|}{ MBBS II year } & \multicolumn{2}{|c|}{$\begin{array}{l}\text { MBBS III year } \\
\text { part-I }\end{array}$} & \multicolumn{2}{|c|}{$\begin{array}{l}\text { MBBS III year } \\
\text { part- II }\end{array}$} & \multirow{2}{*}{\multicolumn{2}{|c|}{$p$ value }} \\
\hline & & $N$ & & & $\mathbf{N}$ & $\%$ & $N$ & $\%$ & $\mathbf{N}$ & $\%$ & & \\
\hline \multicolumn{13}{|c|}{$\begin{array}{l}\text { Do you enjoy being in virtual learning environment and learn the experiments using virtual learning } \\
\text { environment labs? }\end{array}$} \\
\hline Very good & 2 & & & 0 & & $0.0 \%$ & 6 & $13.0 \%$ & 3 & $10.3 \%$ & 11 & \multirow{5}{*}{$<0.001^{*}$} \\
\hline Good & 1 & & & 1 & & $3.6 \%$ & 19 & $41.3 \%$ & 9 & $31.0 \%$ & 30 & \\
\hline Fair & 18 & & & 15 & & $53.6 \%$ & 16 & $34.8 \%$ & 10 & $34.5 \%$ & 59 & \\
\hline Poor & 6 & & & 6 & & $21.4 \%$ & 2 & $4.3 \%$ & 5 & $17.2 \%$ & 19 & \\
\hline Very Poor & 0 & & & 6 & & $21.4 \%$ & 3 & $6.5 \%$ & 2 & $6.9 \%$ & 11 & \\
\hline \multicolumn{13}{|c|}{$\begin{array}{l}\text { Grade the virtual learning environment which helps you in understanding the concept instead of by } \\
\text { hearting them }\end{array}$} \\
\hline Very good & 1 & & & 0 & & $0.0 \%$ & 7 & $15.2 \%$ & 4 & $13.8 \%$ & 12 & \multirow{5}{*}{$<0.001^{*}$} \\
\hline Good & 6 & & & 3 & & $10.7 \%$ & 16 & $34.8 \%$ & 8 & $27.6 \%$ & 33 & \\
\hline Fair & 19 & & & 24 & & $85.7 \%$ & 19 & $41.3 \%$ & 17 & $58.6 \%$ & 79 & \\
\hline Poor & 0 & & & 0 & & $0.0 \%$ & 1 & $2.2 \%$ & 0 & $0.0 \%$ & 01 & \\
\hline Very Poor & 1 & & & 1 & & $3.6 \%$ & 3 & $6.5 \%$ & 0 & $0.0 \%$ & 05 & \\
\hline
\end{tabular}




\begin{tabular}{|c|c|c|c|c|c|c|c|c|c|}
\hline \multicolumn{10}{|c|}{ Grade the problem faced any technical issues in connection to virtual classroom? } \\
\hline Very good & 0 & $0.0 \%$ & 0 & $0.0 \%$ & 0 & $0.0 \%$ & 1 & $3.4 \%$ & \multirow{5}{*}{$0.013^{*}$} \\
\hline Good & 7 & $25.9 \%$ & 4 & $14.3 \%$ & 10 & $21.7 \%$ & 6 & $20.7 \%$ & \\
\hline Fair & 13 & $48.1 \%$ & 15 & $53.6 \%$ & 21 & $45.7 \%$ & 20 & $69.0 \%$ & \\
\hline Poor & 1 & $3.7 \%$ & 8 & $28.6 \%$ & 12 & $26.1 \%$ & 2 & $6.9 \%$ & \\
\hline Very Poor & 6 & $22.2 \%$ & 1 & $3.6 \%$ & 3 & $6.5 \%$ & 0 & $0.0 \%$ & \\
\hline \multicolumn{10}{|c|}{ How convenient was the timing of virtual classroom } \\
\hline Very good & 3 & $11.1 \%$ & 4 & $14.3 \%$ & 13 & $28.3 \%$ & 7 & $24.1 \%$ & \multirow{5}{*}{0.077} \\
\hline Good & 10 & $37.0 \%$ & 17 & $60.7 \%$ & 22 & $47.8 \%$ & 16 & $55.2 \%$ & \\
\hline Fair & 14 & $51.9 \%$ & 6 & $21.4 \%$ & 11 & $23.9 \%$ & 5 & $17.2 \%$ & \\
\hline Poor & 0 & $0.0 \%$ & 0 & $0.0 \%$ & 0 & $0.0 \%$ & 1 & $3.4 \%$ & \\
\hline Very Poor & 0 & $0.0 \%$ & 1 & $3.6 \%$ & 0 & $0.0 \%$ & 0 & $0.0 \%$ & \\
\hline \multicolumn{10}{|c|}{ How do you rate quality of virtual classroom in relation to $A-V$ aids } \\
\hline Very good & 5 & $18.5 \%$ & 1 & $3.6 \%$ & 12 & $26.1 \%$ & 5 & $17.2 \%$ & \multirow{5}{*}{$<0.001^{*}$} \\
\hline Good & 8 & $29.6 \%$ & 18 & $64.3 \%$ & 21 & $45.7 \%$ & 17 & $58.6 \%$ & \\
\hline Fair & 7 & $25.9 \%$ & 7 & $25.0 \%$ & 13 & $28.3 \%$ & 7 & $24.1 \%$ & \\
\hline Poor & 7 & $25.9 \%$ & 0 & $0.0 \%$ & 0 & $0.0 \%$ & 0 & $0.0 \%$ & \\
\hline Very Poor & 0 & $0.0 \%$ & 2 & $7.1 \%$ & 0 & $0.0 \%$ & 0 & $0.0 \%$ & \\
\hline \multicolumn{10}{|c|}{$\begin{array}{l}\text { Is it that the virtual learning environment helps you to understand a concept in a much better way as } \\
\text { compared to traditional methods? }\end{array}$} \\
\hline Very good & 2 & $7.4 \%$ & 0 & $0.0 \%$ & 12 & $26.1 \%$ & 3 & $10.3 \%$ & \multirow{5}{*}{$<0.001^{*}$} \\
\hline Good & 4 & $14.8 \%$ & 1 & $3.6 \%$ & 10 & $21.7 \%$ & 8 & $27.6 \%$ & \\
\hline Fair & 9 & $33.3 \%$ & 13 & $46.4 \%$ & 18 & $39.1 \%$ & 16 & $55.2 \%$ & \\
\hline Poor & 11 & $40.7 \%$ & 9 & $32.1 \%$ & 3 & $6.5 \%$ & 1 & $3.4 \%$ & \\
\hline Very Poor & 1 & $3.7 \%$ & 5 & $17.9 \%$ & 3 & $6.5 \%$ & 1 & $3.4 \%$ & \\
\hline \multicolumn{10}{|c|}{ Grade teachers' efficiency in virtual classroom compare to traditional method } \\
\hline Very good & 1 & $3.7 \%$ & 7 & $25.0 \%$ & 4 & $8.7 \%$ & 0 & $0.0 \%$ & \multirow{5}{*}{$<0.001^{*}$} \\
\hline Good & 2 & $7.4 \%$ & 10 & $35.7 \%$ & 20 & $43.5 \%$ & 11 & $37.9 \%$ & \\
\hline Fair & 18 & $66.7 \%$ & 7 & $25.0 \%$ & 10 & $21.7 \%$ & 12 & $41.4 \%$ & \\
\hline Poor & 0 & $0.0 \%$ & 4 & $14.3 \%$ & 0 & $0.0 \%$ & 0 & $0.0 \%$ & \\
\hline $\begin{array}{l}\text { No } \\
\text { Change }\end{array}$ & 6 & $22.2 \%$ & 0 & $0.0 \%$ & 12 & $26.1 \%$ & 6 & $20.7 \%$ & \\
\hline \multicolumn{10}{|c|}{ How do you rate online examination conducted for your internal assessment } \\
\hline Very good & 15 & $55.6 \%$ & 0 & $0.0 \%$ & 20 & $43.5 \%$ & 3 & $10.3 \%$ & \multirow{5}{*}{$<0.001^{*}$} \\
\hline Good & 2 & $7.4 \%$ & 2 & $7.1 \%$ & 20 & $43.5 \%$ & 17 & $58.6 \%$ & \\
\hline Fair & 8 & $29.6 \%$ & 19 & $67.9 \%$ & 3 & $6.5 \%$ & 7 & $24.1 \%$ & \\
\hline Poor & 0 & $0.0 \%$ & 1 & $3.6 \%$ & 1 & $2.2 \%$ & 2 & $6.9 \%$ & \\
\hline Very Poor & 2 & $7.4 \%$ & 6 & $21.4 \%$ & 2 & $4.3 \%$ & 0 & $0.0 \%$ & \\
\hline \multicolumn{10}{|c|}{ What is your expectation about your result with virtual classroom } \\
\hline Very good & 2 & $7.4 \%$ & 0 & $0.0 \%$ & 14 & $30.4 \%$ & 3 & $10.3 \%$ & \multirow{5}{*}{$<0.001^{*}$} \\
\hline Good & 14 & $51.9 \%$ & 1 & $3.6 \%$ & 23 & $50.0 \%$ & 14 & $48.3 \%$ & \\
\hline Fair & 10 & $37.0 \%$ & 13 & $46.4 \%$ & 6 & $13.0 \%$ & 12 & $41.4 \%$ & \\
\hline Poor & 0 & $0.0 \%$ & 12 & $42.9 \%$ & 1 & $2.2 \%$ & 0 & $0.0 \%$ & \\
\hline Very Poor & 1 & $3.7 \%$ & 2 & $7.1 \%$ & 2 & $4.3 \%$ & 0 & $0.0 \%$ & \\
\hline
\end{tabular}




\begin{tabular}{|l|c|c|c|c|c|c|c|c|c|}
\hline What is your overall experience about the virtual classroom \\
\hline Very good & 2 & $7.4 \%$ & 0 & $0.0 \%$ & 9 & $19.6 \%$ & 4 & $13.8 \%$ & \\
\hline Good & 7 & $25.9 \%$ & 1 & $3.6 \%$ & 29 & $63.0 \%$ & 16 & $55.2 \%$ \\
\hline Fair & 15 & $55.6 \%$ & 24 & $85.7 \%$ & 5 & $10.9 \%$ & 8 & $27.6 \%$ & $<0.001 *$ \\
\hline Poor & 3 & $11.1 \%$ & 1 & $3.6 \%$ & 2 & $4.3 \%$ & 1 & $3.4 \%$ & \\
\hline Very Poor & 0 & $0.0 \%$ & 2 & $7.1 \%$ & 1 & $2.2 \%$ & 0 & $0.0 \%$ & \\
\hline Total & 27 & $100.0 \%$ & 28 & $100.0 \%$ & 46 & $100.0 \%$ & 29 & $100.0 \%$ & \\
\hline
\end{tabular}

\section{Positive response for the following questions}

\begin{tabular}{|c|c|c|c|c|c|c|c|c|c|}
\hline $\begin{array}{l}\text { Do you feel that virtual } \\
\text { learning environments } \\
\text { helps you to recollect } \\
\text { the learning very easily } \\
\text { even after the one } \\
\text { month }\end{array}$ & 1 & $3.7 \%$ & 1 & $3.6 \%$ & 19 & $41.3 \%$ & 10 & $34.5 \%$ & $<0.001^{*}$ \\
\hline $\begin{array}{l}\text { Do you think, reading } \\
\text { the same concept from } \\
\text { the book makes more } \\
\text { sense after virtual } \\
\text { learning environment? }\end{array}$ & 14 & $51.9 \%$ & 26 & $92.9 \%$ & 39 & $84.8 \%$ & 28 & $96.6 \%$ & $<0.001^{*}$ \\
\hline $\begin{array}{l}\text { Do you feel bore in } \\
\text { virtual learning } \\
\text { environment? }\end{array}$ & 18 & $66.7 \%$ & 25 & $89.3 \%$ & 12 & $26.1 \%$ & 12 & $41.4 \%$ & $<0.001^{*}$ \\
\hline $\begin{array}{l}\text { Do you think when you } \\
\text { were not using virtual } \\
\text { learning you were an } \\
\text { average student but } \\
\text { after its use you are an } \\
\text { above average student }\end{array}$ & 1 & $3.7 \%$ & 0 & $0.0 \%$ & 14 & $30.4 \%$ & 5 & $17.2 \%$ & $0.001^{*}$ \\
\hline $\begin{array}{l}\text { Effective discussion } \\
\text { environment was } \\
\text { provided for Virtual } \\
\text { Class Environment? }\end{array}$ & 14 & $51.9 \%$ & 13 & $46.4 \%$ & 41 & $89.1 \%$ & 25 & $86.2 \%$ & $<0.001^{*}$ \\
\hline $\begin{array}{l}\text { Could you reach the } \\
\text { faculty easily and asked } \\
\text { your questions? }\end{array}$ & 16 & $59.3 \%$ & 25 & $89.3 \%$ & 42 & $91.3 \%$ & 29 & $100.0 \%$ & $<0.001^{*}$ \\
\hline $\begin{array}{l}\text { Was the timetable } \\
\text { distributed prior to your } \\
\text { schedule? }\end{array}$ & 23 & $85.2 \%$ & 18 & $64.3 \%$ & 44 & $95.7 \%$ & 29 & $100.0 \%$ & $<0.001^{*}$ \\
\hline $\begin{array}{l}\text { Do you think it's easy for } \\
\text { teachers to teach } \\
\text { practical modules using } \\
\text { virtual learning } \\
\text { environments? }\end{array}$ & 0 & $0.0 \%$ & 2 & $7.1 \%$ & 24 & $52.2 \%$ & 13 & $44.8 \%$ & $<0.001^{*}$ \\
\hline $\begin{array}{l}\text { Do you prefer to } \\
\text { continue the same } \\
\text { method of teaching? }\end{array}$ & 10 & $37.0 \%$ & 1 & $3.6 \%$ & 25 & $54.3 \%$ & 15 & $51.7 \%$ & $<0.001^{*}$ \\
\hline $\begin{array}{l}\text { Have faced any problem } \\
\text { in managing attendance } \\
\text { during online classes }\end{array}$ & 15 & $55.6 \%$ & 4 & $14.3 \%$ & 13 & $28.3 \%$ & 12 & $41.4 \%$ & $0.008^{*}$ \\
\hline $\begin{array}{l}\text { Do you think online } \\
\text { education should be } \\
\text { used as supplement or } \\
\text { regular }\end{array}$ & 17 & $63.0 \%$ & 2 & $7.1 \%$ & 28 & $60.9 \%$ & 18 & $62.1 \%$ & $<0.001^{*}$ \\
\hline
\end{tabular}


Advantages

- Don't have to get ready and walk to classroom

- Easy to understand, re -collectible and comfortable

- Regular and in touch with studies

- PPT is easily available \& flexible schedule

- Maintained the social distancing

- Don't get tired

- Comfortably study in my room

- PPT is easily available

- During COVID- 19 this is an effective method and helps us to be safe.

\section{Disadvantages}

- Practical part, Postings and field visits are missed and patient interaction

- Network issues

- Lots of distraction \& poor attention

- Monotonous, laziness develops

- Hard to concentrate

- Students are not completely understanding

- Creates an illusion in everyone's mind that our course is not getting affected because of the pandemic

- Teachers don't really know what students are doing behind the gadgets

- Approaching teachers regarding doubts is not effective

Similarly we collected responses with regards to make student active in a virtual classroom and suggestions for improving online teaching. The responses were as follows:

- Attendance will be taken at any point of the class.

- Calling out names, roll number and ask questions

- By showing interesting videos or modules

- Regular written tests

- Organizing Tutorials, seminars, clinical based problems .MCQ and other activities for the students

- More interaction by teacher

- Some of them have mentioned no suggestions and nothing to improve, it is already best.
Students were also asked about their experience on virtual viva -voce exam, their responses are:

- It was better than expected. Just like our normal viva-voce exam and conducted in a very proper manner. Many of them expressed in the form of a thank you note for conducting it in such an efficient way.

- Awesome and very interactive, watched their recorded video and has helped them to improve their performance.

- Teachers asked questions on almost all topics for 10 minutes and got to know their weak topics

- Connection issues but the response from the IT department was quick and helpful.

\section{Discussion}

In the present study the perception of students with regards to the virtual classroom was good because it has many advantages like flexibility, accessibility from anywhere in the country and also possible to watch recorded lectures whenever they want etc. The similar findings were observed with regards to flexibility in term of time, place and pace in a virtual classroom experience (Dilani, 2014) In another study reported the benefit of the virtual classroom is they can learn their own pace as they are, rewind, replay and students who fail to attend formal classes due to illness can watch recorded lectures later also (Virtual Classroom, 2020).

Our study also observed some disadvantages of virtual classrooms like network problems, practical problems like hands- on training, field visits and Patient interactions etc. are not possible with virtual classrooms. similar finding in another study, like practical aspects are missing on the distance learning during the pandemic although, students have learned but getting the right explanation will be a challenge to them especially with the new concepts and especially if hands-on is required (Nasser, 2020).

Many of the students said a virtual classroom is an alternative option during emergencies but not as a permanent method of teaching. 
Different studies also have commented the same opinion that they cannot totally replace the traditional classroom teaching due to the lack of interaction and personal touch, which is an especially important component of medical education (Bhargava, 2020)

\section{Conclusion \& Recommendations}

The finding of the present study concludes that the use of virtual classrooms has many advantages and disadvantages. But at the same time, students preferred the traditional method as the best method of teaching only; in emergencies like COVID -19 pandemic we can use it as an alternate method of teachinglearning. Many of the suggestions were given by students for improvement and to make it more interactive like organizing group discussion, tutorials, MCQ test, and clinical case discussion, quiz competition, etc. We recommend the university to adopt a virtual classroom for all the teaching- learning domains like cognitive, psychomotor and affective assessment by giving training to both staff and students in learning management system.

\section{References}

Bhargava, S. 2020. Online Classes for Medical Students During COVID-19 Pandemic: Through the Eyes of the Teaching Faculty, J Res Med Dent Sci, 8 (4) pp. 189-192.

Dilani S. P G. 2014 . Students' experiences of learning in a virtual classroom International Journal of Education and Development using Information and Communication Technology(IJEDICT), , Vol. 10, Issue 4, pp. 93101. Available at http://ijedict.dec.uwi.edu /viewarticle. php?id=1845 (Accessed $1 \mathrm{Feb}$ 2021).

Nasser A. Saif Almuraqab, 2020. Shall Universities at the UAE Continue Distance Learning After the COVID-19 Pandemic? Revealing Students' Perspective, International Journal of Advanced Research in Engineering and Technology (IJARET), 11(5), pp. 226-233.

Saiyad S, Virk A, Mahajan R, Singh T, 2020. Online teaching in medical training: establishing good online teaching practices from cumulative experience. Int J App Basic Med Res, 10, pp. 149155.

Virtual Classroom, 2020: To Create A Digital Education System in Bangladesh. International Journal of Higher Education. Vol. 9, No. 3; URL: https://doi.org/10.5430/ijhe.v9n3p129 